\title{
HUMAN MILK BANK: CHALLENGES AND VISIBILITY FOR NURSING
}

\author{
Mônica Barros de Pontes ${ }^{1}$, Tânia Cristina Franco Santos², André Luís Lima Nogueiraª, Maria \\ Angélica de Almeida Peres ${ }^{4}$, Maria Zilma Rios ${ }^{5}$, Antonio José de Almeida Filho
}

${ }^{1}$ M.Sc. in Nursing. Nurse, Hospital Universitário, Universidade Federal do Espírito Santo (UFES). Vitória, Espírito Santo, Brazil. E-mail:
monicabpontes@gmail.com
${ }^{2}$ Ph.D. in Nursing. Professor, Universidade Federal do Rio de Janeiro (UFRJ). Rio de Janeiro, Rio de Janeiro. Brazil. E-mail:
taniacristinafsc@terra.com.br
${ }^{3}$ Ph.D. in History. UFES. Vitória, Espírito Santo, Brazil. E-mail: guazo08@gmail.com
${ }^{4}$ Ph.D. in Nursing. Professor, UFRJ. Rio de Janeiro, Rio de Janeiro. Brazil. E-mail: angélica.ufrj@uol.com.br
${ }^{5}$ M.Sc. in History. Hospital Universitário UFES. Vitória, Espírito Santo, Brazil. E-mail: zilmarios@globo.com
${ }^{6}$ Ph.D. in Nursing. Professor, UFRJ. Rio de Janeiro, Rio de Janeiro. Brazil. E-mail: ajafilhos@gmail.com

\section{ABSTRACT}

Objective: analyze the implementation process of the human milk bank of a university hospital in the state of Espírito Santo and discuss the implications of this deployment to the regional nursing practice.

Method: in this historical and social search the primary sources were interviews conducted with eight nurses, and documents from the nursing section. The thematic content analysis and the theoretical framework of Pierre Bourdieu allowed mediation of the objective and subjective dimensions of the social world.

Results: it was evidenced that the milk bank was designed in 1993 and implemented in 1994 by three nurses and a doctor. In its historical path, the human milk bank had the participation of nurses involved in knowledge-power relations marked by symbolic violence and resistance to the hegemonic medical power of the time.

Conclusion: it was concluded that the implementation of a human milk bank did not happen as anticipated by the public policy of the time, which was the result of a complex power game involving health professionals and the institution itself.

DESCRIPTORS: Nursing. Human milk banks. History of nursing.

\section{BANCO DE LEITE HUMANO: DESAFIOS E VISIBILIDADE PARA A ENFERMAGEM}

\section{RESUMO}

Objetivo: analisar o processo de implantação do banco de leite humano de um hospital universitário do Estado do Espírito Santo e discutir suas implicações para a enfermagem capixaba.

Método: pesquisa histórico-social, cujas fontes primárias foram depoimentos de oito enfermeiras, documentos dos acervos da Divisão de Enfermagem. A análise de conteúdo temático e o referencial teórico de Pierre Bourdieu permitiram mediar as dimensões objetivas e subjetivas do mundo social.

Resultado: evidenciou-se que o banco de leite foi idealizado em 1993 e implantado em 1994, por três enfermeiras e uma médica. Em sua trajetória histórica contou com a participação de enfermeiras envolvidas em relações de saber-poder demarcadas por violências simbólicas e resistências ao poder médico hegemônico da época.

Conclusão: conclui-se que a implantação do banco de leite não aconteceu como previa a política pública para esse fim, resultado de um complexo jogo de poder, envolvendo os profissionais da saúde e a própria instituição.

DESCRITORES: Enfermagem. Bancos de leite humano. História da enfermagem. 


\section{BANCO DE LECHE HUMANO: RETOS Y VISIBILIDAD DE ENFERMERÍA}

\section{RESUMEN}

Objetivo: analizar el proceso de implantación del banco de leche humano de un hospital universitario del Estado de Espírito Santo y discutir las implicaciones de esa implantación para la enfermería local son los objetivos de este estudio.

Metodo: es una Investigación histórico-social. Las fuentes primarias fueron testimonios de ocho enfermeras, documentos del acervo de la División de Enfermería. El análisis de contenido temático y el marco teórico de Pierre Bourdieu permitió mediar en las dimensiones objetivas y subjetivas del mundo social.

Resultados: el banco de leche fue concebido en 1993 y ejecutado en 1994 por tres enfermeras y una médica. En su trayectoria histórica, el bancos de leche humano contó con la participación de enfermeras implicadas en relaciones de saber-poder demarcadas por violencias simbólicas y resistencias al poder médico hegemónico de la época.

Conclusión: la implantación del bancos de leche humano no aconteció como previa la política pública para ese fin, resultado de un complejo juego de poder involucrando los profesionales de la salud y la propia institución.

DESCRIPTORES: Enfermería. Bancos de leche humano. Historia de la enfermería.

\section{INTRODUCTION}

The object of this study was the process of implementation and consolidation of the service provided by the Human Bank Milk (HMB) of the University Hospital Cassiano Antônio de Morais (HUCAM), at the Universidade Federal do Espirito Santo (UFES). The study time frame starts in 1993, when the HMB/HUCAM was planned, and finishes in 1998, when the activities provided by this service were recognized, initiating a project for the construction of its third and current facility.

In Brazil, throughout the $20^{\text {th }}$ century, economic transformations occurred, resulting in Brazilian society adopting an urban and industrial model, resocializing the working man, and imposing a bourgeois family model in which the woman is active part of the labor market. In this consumer society model, regarding the area of maternal and child health, breastfeeding is discouraged and the feeding bottle appears as a symbol of modernity and urbanism. This phenomenon is enhanced in the scientific environment, which understood it as an ideal therapeutic alternative to infant feeding in the 1970s. ${ }^{1-3}$

In the setting of infant feeding, the overwhelming advance of industrialized milks was observed in Brazil, along with poor infant health conditions. In the 1980s, there was a confrontation between the marketing of infant formulas and pro-breastfeeding campaigns using scientific articles in support of breastfeeding. In the 1990s, commercial weaning prevailed as an alternative for the infant weight gain. ${ }^{1,4-5}$

The representation of infant feeding was a serious public health grievance, which in the 1980s led the Ministry of Health to use reversion of weaning as one of the main strategies to reduce infant morbidity and mortality. ${ }^{2,5-7}$
At the time, institutional initiatives and state actions, such as the promotion of the breastfeeding, were followed by social mobilizations in favor of the fostering of breastfeeding. Therefore, some mothers organized themselves and created a movement called Grupo de Mães Amigas do Peito (Friends of the Breast Mother's Group), founded in 1980, in the city of Rio de Janeiro. These mobilizations and social changes contributed to the action of the National Breastfeeding Incentive (Programa Nacional de Incentivo ao Aleitamento Materno PNIAM) Program, of Feeding and Nutrition National Institute (Instituto Nacional de Alimentação e Nutrição INAN), which since 1981 began to coordinate and discipline the implantation of HMB in Brazil, aiming to reduce infant morbidity and mortality and improve Brazilian children's quality of life. ${ }^{8-9}$

To better enhance the advantages of human milk, national and international studies highlighted the superiority of maternal milk. ${ }^{10}$ The efficiency of breastfeeding and/or the use of human milk through milk banks provide nutritional and non-nutritional benefits to the infant in all stages of life. Therefore it deserves special attention, in some countries, to the beginning and the duration of breastfeeding. ${ }^{11-12}$ Scientific evidence showed a greater increase of intellect in breastfed children than children who were fed with infant formula, enhancing one of the long-term benefits in human health. For this purpose, it is important to initiate early interventions in the postpartum period, because they influence the efficiency of breastfeeding. ${ }^{13-15}$

Because of this, throughout the years, the HMBs have undergone important fluctuations, from a support structure to exceptionalities of commercial weaning, to the implantation of the first unit in Brazil - the Fernandes Figueira Institute/Oswaldo Cruz Foundation (FIOCRUZ), in 
1943 - to meet the needs of children who could not feed on milk formulas. This first HMB functioned as specialized center, responsible for the activities of collection, processing, and quality control of human milk, which was collected for later distribution under prescription by a doctor or nutritionist. ${ }^{1-2,13}$

We can see, in a brief chronology, that in Brazil there was an expansion of HMB from the first initiative, reaching 47 units in the 1980s. It is noteworthy that, in the late 1980s, the state of Espírito Santo had two HMBs that, as well as the other banks in the country, still had the purpose of offering human milk only in emergency situations. Therefore it was prohibited in those cases that could be solved with artificial milk, which was always the first option. The first HMB in the state of Espírito Santo was headquartered in Santa Casa de Misericórdia and was created in 1988. Throughout 17 years this bank functioned with many difficulties and inside an inadequate structure. ${ }^{8,13}$

From 1985 we begin to see in Brazil a new outlook for the HMBs, through technical recommendations for their functioning. ${ }^{2}$ An agreement signed in 1986 between INAN and FIOCRUZ strengthens the expansion of this service that reaches, in the 1990s, 104 units. This agreement makes the HMB of Fernandes Figueira Institute, under the coordination of Dr. João Aprígio, a national reference center for the milk bank, with the purpose of promoting, protecting, and supporting breastfeeding. With the restructure of PNIAM, in 1993, the HMB Central Commission was created, bonded to the Ministry of Health, and responsible for the assistance of the formulation and implementation of politics for this sector. ${ }^{1-5}$

In view of this situation, we elaborated the following objectives: to analyze the implementation process of HMB/HUCAM in the state of Espírito Santo and to discuss the implications of this implementation for nursing in this state.

With this initiative, the present study, registered in the Núcleo de Pesquisa de História da Enfermagem Brasileira (Nuphebras) - (Research Center of Brazilian Nursing History) contributes to the understanding of the insertion of nursing into actions promoting maternal breastfeeding. It thereby equally strengthens the initiatives that aim for the reconstruction of nursing history in the state of Espírito Santo in terms of care practice, articulated through teaching and research in nursing.

\section{METHOD}

This is a historical and social qualitative study. The documentary corpus of the study consisted of written documents and oral statements. The written documents are letters, memoranda, ordinances, rules, and routines of the HMB's functioning service related to the time period of the study. These documents are filed in the folder of the Nursing Section of the HUCAM and were selected in the period of January to December 2013.

We collected the oral statements of eight nurses who worked in the maternity services, neonatal intensive care unit, and ambulatories of pediatrics, gynecology, and obstetrics of the HUACAM. Everyone participated directly or indirectly in the implantation of the HMB.

Regarding the oral statements, inclusion criteria for the collaborators were adopted, such as: to have worked in the maternity services; in the intensive care unit; in the neonatal intensive care unit; or in the pediatrics, gynecology, and obstetrics ambulatories of the HUCAM; and to have directly or indirectly participated in the implementation of the HMB from 1993 to 1998. To recruit the agents, searches were first performed in the turn shifts of the health professionals. After the agents' identification, we requested that the human resources department of the hospital provide the agents' addresses and telephone numbers so that we could schedule the interviews.

For identification of the statements, we used the first letter of the name, which was authorized by the deponent, followed by the number corresponding to the sequential order of the interviews. The interviews were digitally recorded and, subsequently, they were transcribed and validated by the agents, through reading and verbal and written authorization for their use. The average time of the interviews was two hours, at sites chosen by the interviewees. The predominant choice was the interviewee's residence and, in some cases, the HMB/HUCAM itself. The interviews were guided by a script with discursive questions about the subject. The script included general questions for all interviewees, as well as a chronology of the events that occurred in the investigated period and were considered important regarding the study object.

The secondary sources consisted of a bibliographic collection on the subject to support the description of this research. In the analysis of the documentary body, active interrogation procedures were developed, with an independent stance regarding 
the official version, to better derive the findings of these documents. To ensure the reliability of the results, we evaluated the set of documents and not the isolated ones.

The setting is the Hospital Universitário Cassiano Antônio de Morais, built in 1938, located in the city of Vitória, capital of the state of Espírito Santo. It was inaugurated in 1942, as Sanatório Getúlio Vargas (Getúlio Vargas Sanatorium), and in 1967 it was given to the Federal University of Espírito Santo (UFES) under the name of Hospital das Clínicas (Clinics Hospital). In the 1980s, it was named HUCAM, through Resolution N. 12/1980 of the University Council. At the time of its expansion, in 1980, it had 265 operational beds, and the maternity unit was a high-risk reference, with 40 beds, 30 for obstetrics, and 10 for gynecology, in addition to the delivery room with four beds. It had a nursing team comprising 48 mid-level professionals who attended the maternity unit, in addition to a team that attended the intensive care unit with 24 neonatal beds. ${ }^{13}$

The data were analyzed using the thematic content concept of Minayo. ${ }^{16}$ The theoretical and philosophical framework of Pierre Bourdieu allowed us to understand the mediation between the objective and subjective dimensions of the social world, because the structure of the nurses' practices in the hospital setting, when fighting for the recognition of their scientific capital, was not a result of mechanical process from the outside to the inside, nor was it from a process conducted autonomously by the individual subjects. The positive result originated from structured strategies (practical and social) consonant with the social position of the person who produced them. They were impregnated with the individual's subjectivity, preferences, aspirations, and ways of perceiving and appreciating the world, ultimately, the habitus. ${ }^{17-19}$

The concepts of habitus and field will be used in this study, more directly related to the actions reportable to "make science" and the agents involved in this process. Therefore, the concept of "scientific capital" is also important, as a species of symbolic capital and the various uses that equally various agents also make out of the sciences. ${ }^{17}$ From this perspective, it is possible to problematize a usual type of perception of facing scientific production as something that originates and reproduces "in itself." Questioning this type of vision, Bourdieu reaches the following hypothesis: [...] between these two poles [text content of a production and social context], very distant, among which it is supposed, a little recklessly, that the bonding can be made, there is an intermediate universe, which I call literary, artistic, legal or scientific field, which means, the universe in which there are the agents and the institutions that produce, reproduce and spread the art, the literature or science. This universe is a social world as the others, but it obeys the more or less specific social laws. The idea of field is there to designate this relatively autonomous space, this microcosm endowed with its own laws. ${ }^{18: 20}$

This study was conducted according to Resolution N. 466/12 of the National Health Council, approved by the Research and Ethics Committee of the UFES with report number 970.725, and authorized by the direction of the HUCAM.

\section{RESULTS}

\section{Implantation of the Human Milk Bank of the Cassiano Antônio de Moraes University Hospital and the appearance of a new locale of nursing action}

The resumption of the insertion of nursing in the direct care of the client, in order to strengthen the recognition and the professional space, was a resource of great importance in the planning of measures to improve the breastfeeding practice. Without neglecting the management practice, and associating care and teaching practices, some nurses searched for new ways to improve their position in the HUCAM. The following report evidences the perception of the need for qualification of these professionals to better take pro-breastfeeding actions: [...] in 1992 there was in the HUCAM ambulatory a beginning of work. We were beginning to work with breastfeeding [...] in fact, the pediatrics ambulatory already had a group. When this neonatologist came, who was transferred from the city of Rio de Janeiro to the city of Vitoria, she knew about a training in the city of Santos with three jobs; for her, for me and we needed a maternity professional, who was a care nursing recently graduated [...] (MC8).

The insertion of the nurses in the pro-breastfeeding program of the HUCAM seems to have started before the creation of the Human Milk Bank, as we can observe in the excerpts of the following reports: [...] I remember that, in the 80s, when I was reading a study of professor José Martins, I became interested in breastfeeding and I went to Campinas to see his work. [...] It was an initiative of my own because I thought I needed an update [...] (MC8); [...] I wanted to have a specialization in obstetrics and, reading a public notice, I saw the first graduation course in the IFF/RJ 
[Fernandes Figueira Institute/Rio de Janeiro] on Human Milk Bank and breastfeeding. [...] I worked in the maternity section and I wanted to do something different for the clients [...] (MB7);

The appropriation of this capital worked as a chip that provides, to the person who has it, an influential power on the referred field. ${ }^{18-19}$ In the same way, one of the interviewees stated: [...] the work of the maternal breastfeeding for me was essential, because it gave me this strength again, for working with a team $[\ldots](\mathrm{R} 3)$.

We also see the nurses' leadership in the statement of the interviewee: [...] in the 90's, I took the direction of the Nursing Section. I remember the actions made for the maternity section, aiming the title Hospital Amigo da Criança (Child Friendly Hospital) [elaboration of the rules and routines by the nurses] and I remember the modifications for the child in the $H M B$. Innumerous memoranda requesting employees for the job (E2);

It was a hard-working time, many struggles because of many professionals' resistance. [...] (S1).

The initiative for the official creation of the $\mathrm{BLH} / \mathrm{HUCAM}$ resulted in the need to restructure the physical area of the Núcleo de Aleitamento Materno (NUAM) (Breastfeeding Center). ${ }^{20}$ With the need to obtain a new space, the nurse responsible for the service took steps to obtain the new facilities, according to the following transcribed statement: [...] I remember the nurse's letter to the director of the $D A F$ [Departamento Administrativo e Financeiro] [Management and Finance Section] requesting a room in the pediatrics building, as a physical area to the establishment of the milk bank [...] (E2).

Another statement is illustrative, in the sense of evidencing that the achievement of the HMB represented recognition of the work developed in the daily actions related to breastfeeding in the HUCAM: [...] the HMB did not exist. It begins with a very small space, it started growing, growing. It became a great service [...] (S4).

The veracity of the information contained in the statement above is evidenced when, in October 1995, the service was contemplated to include a second physical area, and officially recognized as a HMB.

Among the consulted documents, the memorandum of July 12, 1996, sent to the rector of UFES, makes it clear that there was the essential participation of the students of the Informatics College in the informatization work of the HMB of the HUCAM, ${ }^{21}$ according to the following excerpt from the state- ment: [...] I remember when the HMB coordinator made a partnership with three students o the Informatics College to conduct the HMB informatization as their Term Paper project [Project presented at the end of the college course]. The program was very good and even the coordinator of the HMB National Network came to see it [...] (T5).

The incorporation of this technological innovation was in consonance with the HMB of the Fernandes Figueiras Institute/FIOCRUZ, a national reference service that launched the first software named LacVida. Therefore, the HMB of the HUCAM, after obtaining this resource for its informatization, [...] became the first milk bank of the State to test and use the referred software, formalizing a bond between the HMB/HUCAM, HMB/FIOCRUZ and DATA-SUS [...] (MC8).

With a broad structure, it was equally possible to develop the activities based on the three parts constituted by the care to pregnant women and nursing mothers, human milk processing, and theoretical and practical teaching about breastfeeding.

The turn shifts of the work showed that the professionals were not exclusive to the HMB; most of them shared the tasks between the maternity service and the HMB. In 1996, the nurse who was the technician responsible for the HMB/HUCAM service in the HMB national network was designated by the nursing section to exclusively take on the coordination of the HMB service. This incorporated more than six nursing assistants in the team, according to the register in the Report Book of the Nursing Section of 1996,22 reinforced by the statement of the Nursing leader at the time: [...] I remember how hard it was to release the nurse to work exclusively to the $H M B$, we were not a few at the time, but people did not value this work and thought they would be idle [...] (E2).

The recognition of the HMB work in the HUCAM was also extended to society and to the State Department of Health (SESA). This assertion finds support in the excerpt of the statement below, recalling that the BLH/HUCAM team promoted the training of human resources throughout the state, in addition to being invited to speak on issues of questions related to breastfeeding: [...] the $H M B$ was growing. Initially it did not have much value within HUCAM, but we trained the professionals of State health institutions along with SESA. The HMB solved any problem with breastfeeding, and there was only the nursing in the service [...] (T5).

Additionally, there is the solicitation to the HUCAM for training the employees of the Santa Casa de Misericórdia Hospital, in 1995. This insti- 
tution was a pioneer in HMB in the State: "[...] I request the NUAM's professional team training of the Hospital Santa Casa de Misericórdia of Vitória for the IHAC [Iniciativa Hospital Amigo da Criança] Child Friendly Hospital Initiative." $23: 3$

Notwithstanding, despite the HMB/HUCAM having trained professionals from various institutions, it did not obtain the title of State Reference Human Milk Bank. This caused much dissatisfaction among the nursing team that worked there, as evidenced in the document sent by the HMB coordinators to the HUCAM Nursing Section: [...] We were unpleasantly surprised with the decision [...] of Mr. Secretary of Health of Espírito Santo State, who indicated the HMB of the HDDS [Dr. Dorio Silva Hospital], recently inaugurated, as state reference. Our first surprise is that [...] according to the Ordonnance of the MS, it is attributed to the units that are different from the others because of the care activities and technical assistance [...]. Regarding the facts, the responsible for the child and maternal department coordination of SESA informed that the decision had emergency character $[\ldots] . .^{24: 5}$

Even though the HMB/HUCAM was not given the title of Human Milk Bank of the state of Espírito Santo, it was created inside the reality of this state, offered free care, and became an emergency service for clinical lactation management. It promoted collective actions regarding health education in terms of promotion and prevention, as well as healing actions. Additionally, it promoted courses for pregnant women and nursing mothers, as well as other events for the community.

The HMB of the HUCAM was perceived by the nurses as a place with scientific authority recognized in responding to questions related to breastfeeding, and was recognized by its peers inside the hospital and by the society of Espírito Santo in general: [...] it was a great achievement for us nurses, because we had the opportunity of helping the mothers and seeing a positive result. We were much appreciated by these women, we made many modifications in the routines [...] (ML6).

Consulting the records of the HUCAM reports, we observe that, in 1997, despite the employee reduction by the Ministry of Education and Culture (MEC), the HUCAM had a period of significant institutional, technical, scientific, and management evolution. Ambulatory consultations were expanded, and there was an increased demand for maternity, gynecology, and pediatrics hospitalizations, contributing to the visibility of the HMB actions. It is noteworthy that in 1997 the HMB incorporated new mid-level servers and a new nursing assistant, resulting in a team of 10 professionals: two nurses, five assistants, and three nursing technicians. In the same period, its physical area has undergone subsequent modifications regarding the development of its activities. ${ }^{13}$

The investments performed in the physical area and infrastructure of the HMB/HUCAM resulted in the construction of the third and current physical area of this sector, in partnership with Banco do Brasil, inaugurated in 2000.

\section{DISCUSSION}

Until 1980, health services worked in an unfavorable way in terms of breastfeeding, resulting in new discussions regarding the health professional's role. The need for expansion of the HMB number in Brazil elicited a lack of scientific knowledge in this area. National and international authorities dedicated themselves to the search for breastfeeding incentive strategies in health services and hospitals. Therefore, the Ministry of Health provided breastfeeding courses throughout Brazil, especially from 1985 onward. ${ }^{13}$

It is noteworthy that nursing in the HUCAM in the 1990s was not different from that in other Brazilian regions. Because nurses were prepared to take leading roles, they were responsible for various activities related to management and very distant from direct care for the client. They prioritized functions related to hospital maintenance and the execution of rules and routines instead of clinical assistance. This underutilization of the nurses legitimized a social power related to the strategical positions of power inside a scientific field that resulted in their delegating their care functions to other categories of nursing professionals. ${ }^{13}$

The search for scientific capital was pointed out by the nurses as justification for the attainment of professional recognition and, certainly, regarding the assertion that people are distributed in this field according the volume of the capital and weight of this capital.

In 1993, the Fernandes Figueira Institute (IFF/ FIOCRUZ-RJ) offered a latus sensu specialization course in breastfeeding and HMB. A nurse's participation in this course was essential for the capitalization and specialized knowledge, and with that there was a prominent actuation of the HMB establishment in the HUCAM. This process had the support of National Reference HMB, according to the excerpts: "[...] regarding the recent formation of the NUAM of 
the Espírito Santo Federal University [...] we express interest in sending a representative of NUAM for the course offered by its Institution $[\ldots]^{\prime \prime}{ }^{25: 4}$

The recognition of the need for a professional nurse to accumulate scientific knowledge in order to work in the HMB implantation is exemplary in the sense of evidencing the position in the structure of power relations that define the field. This means that the distribution structure of specific capital is guided by a conscious evaluation of the objective opportunities for profit: "[...] roughly the structure of the field is determined by the scientific capital distribution in a certain moment."17:20 It should also be noted that the breastfeeding specialization course and HMB were offered only once in Brazil. Six health professionals participated in this course, among them three nurses, and one of them was from HUCAM. ${ }^{13}$

The HMB of the HUCAM was idealized in 1993, in partnership with UFES, through a pediatrics nursing internship. This partnership, coordinated by the professor of the nursing department of the UFES, specialized in pediatric nursing. The breastfeeding ambulatory was created as strategical field and, with its expansion, it became the Breastfeeding Center (NUAM) on July 12, 1993. This expanded its activities from ambulatory to hospital level. ${ }^{13,25}$

The records show that the creation of NUAM was an important event in the university field. The ceremony took place in the IC2 auditorium, with the rector at the time, the UNICEF representative, the state and municipal secretaries of health, the mayors of three cities, the department leaders of the hospital, the teachers from the medical, nursing, and dentistry courses of the UFES, and the technical and management professionals. ${ }^{21}$

This social event was a reflection of symbolic power for HUCAM nursing, because it gathered-for the first time in this hospital, in an event for mothers and children-authorities and other professionals, strengthening a reproduction vector and perpetuation of the domination. The agents' distinguished presence gave renewed significance to breastfeeding, because we have the social facts as products of a social medium that will never be neutral, and this is how we can observe that the hierarchy and power will always be present. The scientific facts are interpreted as social, negotiated inside a (scientific) field of struggles, through scientific capital. ${ }^{17-19}$

The HMB/HUCAM was the third service of this kind to be created in the state of Espírito Santo/Brazil, in 1994, and it is the only one in the state to have a nurse as technically responsible for the national network of the HMB. It is noteworthy that the position taken by the nurse in the network field expresses recognition of its scientific authority regarding the breastfeeding issues in the HUCAM.

In another statement, it was clear that the attainment of the space for the HMB/HUCAM occurred through many struggles on the part of the team. The appropriation of this capital worked as a chip that enables whoever retains it to influence the power in the referred field. ${ }^{18-19}$

After the physical area was established with better conditions, it was not ideal. The nurses of the HMB/HUCAM were able to obtain permanent materials and equipment, such as computers, glassware, machinery, and furniture through the HUCAM, the rectory of UFES, and donations from private institutions.

The new facilities of the HMB/HUCAM were established in prominent areas in the HUCAM structure, highlighting the prestige attributed to this space and, as a consequence, to the agents who occupied it. ${ }^{11}$ This interpretation becomes more expressive when one realizes that the nurse responsible for the HMB/HUCAM remained in the leadership of the service, even after the utilization of a new space and the arrival of a doctor for the service. This translated as a symbolic gain for the HUCAM nursing. It is noteworthy that the spaces appropriated for the agents are properties that situate it and have symbolic value for the social space, because " $[. .$.$] the space is one of the places where$ the power affirms exercises itself".$^{19: 154-5}$ It can be inferred that, especially for the nurses, the HMB/ HUCAM was the most expressive field in nursing in the state of Espírito Santo regarding the authority of knowledge, so that, in this sector, its technical work was recognized in both the health team and civil society.

The recognition regarding the importance of this service for society occurred, partially, because of the importance of maternal milk and breastfeeding, transmitted by women of one generation to the next, leading them to overcome difficulties. ${ }^{26}$ Therefore, those children who, in different situations, could not count on maternal milk through breastfeeding, had the HMB as alternative to obtain maternal milk and its benefits.

\section{CONCLUSION}

This study showed that, in its journey, the HUCAM was successful in the establishment of a HMB, which is historically an important gain for the state 
of Espírito Santo, because the HMB reflects a public policy regarding the issues of breastfeeding, and aims to improve health conditions for mother and child.

It is very important to add that the creation of a HMB, bonded to the Ministry of Health, represented an achievement for the HUCAM. The $\mathrm{HMB} / \mathrm{HUCAM}$ establishment process fostered an institutional policy that became a symbolic gain for nursing, in which a nurse remained active in the coordination even when the view on breastfeeding in the scientific field changed focus. Therefore, a nurse remained in the HMB/HUCAM as an authorized spokesperson for her team, which is an important achievement for nursing.

We observed that the HMB/HUCAM journey demonstrates that this sector was and still is a space for nursing actuation that encourages and promotes breastfeeding through various clinical and educational actions, in addition to the collection, processing, and distribution of the pasteurized human milk with guaranteed quality control. Therefore, the recognition of the nurses' role in the breastfeeding actions, materialized by the professional authorities in the sense of enunciating the legitimate discourse in the issues regarding breastfeeding.

It was possible to observe that nursing established new ways of care, especially in the setting of breastfeeding, searching for new knowledge, practices, and solutions regarding the causes of early weaning, which means that there was a re-updating of the professional habitus. In addition, they occupied a space that was, at first, unappreciated by the other health teams. Overcoming a bureaucratic work philosophy, guided to attend a curative/interventionist model, and assuming a physiological view of care, the nurses demonstrate full capacity to adapt themselves to changes.

\section{REFERENCES}

1. AlmeidaJAG. Amamentação: repensando o paradigma [tese]. Rio de Janeiro (RJ): Instituto Fernandes Figueira - Fundação Oswaldo Cruz, Programa de PósGraduação; 1998.

2. Almeida JAG. Amamentação: um híbrido naturezacultura. Rio de Janeiro (BR): Fiocruz; 1999.

3. Demitto MO, Bercini LO, Rossi RM. Uso de chupeta e aleitamento materno exclusivo. Esc Anna Nery [Internet]. 2013 Jun [cited 2015 Jul 01]; 17(2):271-76. Available from: http://www. scielo.br/readcube/epdf.php?doi=10.1590/ S1414-1452013000200010\&pid =S141481452013000200010\&pdf_path=ean/v17n2/v17n2a10. pdf\&lang=pt
4. Rodrigues AP, Padoim SMM, Guido LA, Lopes LFD. Pre-natal and puerperium factors that interfere on selfefficacy in breastfeeding. Esc Anna Nery [Internet]. 2014 Jun [cited 2016 Mar 01]; 17(2):257-61. Available from: http:/ / www.scielo.br/scielo.php?script=sci_ arttext\&pid=S1414-81452014000200257\&lng=en\&nr $\mathrm{m}=$ iso\&tlng=en

5. Ministério da Saúde (BR), Instituto Nacional de Alimentação e Nutrição. Programa Nacional de Incentivo ao Aleitamento Materno. Brasília (DF): MS; 1991.

6. Grazziotin AL, Grazziotin MCB, Letti LAJ. Disposal of human milk donated to a human milk bank before and after measures to reduce the amount of milk unsuitable for consumption. J. Pediatr [Internet]. 2010 Abr [cited 2015 Jul 01]; 86(4):290-94. Available from: www.scielo.br/pdf/jped/v86n4/a08v86n4.pdf

7. Pacheco STA, Cabral IE. Alimentação do bebê de baixo peso no domicílio: enfrentamentos da família e desafios para a enfermagem. Esc Anna Nery [Internet]. 2011 Jun [cited 2015 Jul 01]; 15(2):314-22. Available from: http:/ / www.scielo.br/scielo.php?script=sci_ arttext\&pid=S1414-81452011000200015\&lng=pt\&nr $\mathrm{m}=$ iso\&tlng $=\mathrm{pt}$

8. Carvalho KEG, Carvalho MEG, CavalcantiSH, Araújo EC. História e memórias do banco de leite humano do Instituto de Medicina Integral Prof. Fernando Figueira (1987-2009). Rev. Bras. Saude Mater. Infant [Internet]. 2010 Dez [cited 2015 Jul 01]; 10(4):314-22. Available from: http:/ / www.scielo.br/scielo.php?script=sci_ arttext\&pid=S1519-38292010000400008\&lng=en

9. Rea MF. Reflexões sobre a amamentação no Brasil: de como passamos a 10 meses de duração. Cad. Saúde Pública. December 12, 2003; 19(1 supplement):S37-45.

10. Conceição CS, Alves VH, Silva LR, Martins CA, Mattos DV, Rodrigues DP. Quality care of the bank of human milk: the perception of users. Rev enferm UFPE online [Internet]. 2013 May [cited 2015 May 20]; 07(5):1271-78. Available from: http://www.revista. ufpe.br/revistaenfermagem/index.php/revista/ article/view/4280/pdf_2589

11. Nisi GD, Arslanoglu S, Ambruzzi AM, Biasini A, Profeti C, Tonetto P, et al. Survey of Italian human milk banks. Journal of Human Lactation. J Hum Lact [Internet]. 2015 Feb [cited 2016 Mar 28]; 31(2):294300. Available from: http:// www.ncbi.nlm.nih.gov/ pubmed/25722356

12. Tuthill EL, McGrath JM, Graber M, Cusson RM, Young SL. Breastfeeding self-efficacy: a critical review of available instruments. J Hum Lact [Internet]. $2015 \mathrm{Aug}$ [cited 2016Mar28];32(1):01-11. Availablefrom: https:/ / www.researchgate.net/publication/281484116_ Breastfeeding_Self-efficacy_A_Critical_Review_of_Available_Instruments

13. Pontes MB, Santos TCF. A inserção das enfermeiras na implantação das políticas de aleitamento materno: o caso do Hospital Universitário Cassiano Antonio de 
Moraes - HUCAM (1992-1994). Enferm Atual. 2009; 50(2): 13-16.

14. Costa LKO, Queiroz LLC, Queiroz RCCS, Ribeiro TSF, Fonseca MSS. Importância do aleitamento materno exclusivo: uma revisão sistemática da literatura. Rev Ciênc. Saúde [Internet]. 2013 Jan [cited 2016 Mar 28]; 15(1):39-46. Available from: http://www. periodicoseletronicos.ufma.br/index.php/rcisaude/ article/view/1920

15. Erin JH, Rachel F, Emily S, Linda N, Marie C. Breastfeeding self-efficacy, mood, and breastfeeding outcomes among primiparous women. J Hum Lact [Internet]. 2015 Mar [cited 2016 Mar 28]; 31(3):51118. Available from: http://www.ncbi.nlm.nih.gov/ pubmed/25829478.

16. Minayo MCS. O desafio do conhecimento: pesquisa qualitativa em saúde. São Paulo (BR): Hucitec; 2000.

17. Bourdieu P. Os usos sociais da ciência: por uma sociologia clínica do campo científico. São Paulo (BR): Editora UNESP; 2004.

18. Bourdieu P. Para uma sociologia da ciência. Lisboa (PT): Edições 70; 2004.

19. Bourdieu P. A produção da crença: contribuição para uma economia dos bens simbólicos. São Paulo (BR): Zouk; 2004.
20. Universidade Federal do Espírito Santo. Hospital Universitário Cassiano Antônio de Morais. Memorando, 27 Jul 1995.

21. Universidade Federal do Espírito Santo. Hospital Universitário Cassiano Antônio de Morais. Memorando, 12 Jul 1996.

22. Universidade Federal do Espírito Santo. Hospital Universitário Cassiano Antônio de Morais. Livro de Registro da Divisão de Enfermagem, 1996.

23. Universidade Federal do Espírito Santo. Hospital Universitário Cassiano Antônio de Morais. Ofício ${ }^{\circ}$ 291, 17 out 1995.

24. Universidade Federal do Espírito Santo. Hospital Universitário Cassiano Antônio de Morais. Memorando, 26 Mar 1999.

25. Universidade Federal do Espírito Santo. Pró - Reitoria de Extensão. Ofício n./93 - PROEXT. Pró - Reitoria de Extensão. Oficio n./93 - PROEXT. Vitória (ES), 26 Jun 1986.

26. Moreira MA, Nascimento ER, Paiva MS. Social representations concerning the breastfeeding practices of women from three generations. Texto Contexto Enferm [Internet]. 2013 Jun [cited 2015 Sep 05]; 22(2):433-41. Available from: http://www. scielo.br/scielo.php?script=sci_arttext\&pid=S010407072013000200020\&lng=pt\&nrm=iso\&tlng=en 